\title{
Sarcopenia and chronic pain in institutionalized elderly women
}

\author{
Sarcopenia e dor crônica em idosas institucionalizadas
}

Caroline Zanin ${ }^{1}$, Joseelen Basso Candido ${ }^{1}$, Matheus Santos Gomes Jorge ${ }^{1,2}$, Lia Mara Wibelinger ${ }^{1,3}$, Marlene Doring ${ }^{1,4}$, Marilene Rodrigues Portella ${ }^{1,5}$

\section{ABSTRACT}

BACKGROUND AND OBJECTIVES: Sarcopenia and chronic pain are geriatric syndromes that negatively impact the lives of the affected elderly, their families and the routine of health services, as is the case of long-term care institutions for the elderly. The objective of this study was to verify the relationship between sarcopenia and chronic pain in institutionalized elderly women. METHODS: A cross-sectional, population-based study was carried out in 24 long-term care institutions for the elderly, in Passo Fundo/RS (December 2016 - June 2017). The population was composed of 161 residents in these places, submitted to an instrument structured in 23 blocks. In this study, blocks A (type of institution), B (sociodemographic variables), F (sarcopenia) and G (chronic pain) were used. Blocks A, B and G were evaluated using the elderly self-report and the block F through the SARC-F Questionnaire. The statistical analysis used the descriptive statistics and the chi-square test with Pearson's relation $(\mathrm{p} \leq 0.05)$.

RESULTS: The sample consisted of 79 elderly women $(81.38 \pm 8.79$ years). The majority between 80 to 89 years, living in private institutions, white, widowed and with 1 to 8 years of education. It was observed that $62 \%$ had sarcopenia and $41.8 \%$ chronic pain, and these variables were associated $(\mathrm{p}=0.033)$. There was no association between sarcopenia or chronic pain with age $(\mathrm{p}>0.05)$.

CONCLUSION: There was an association between sarcopenia and chronic pain in institutionalized elderly women. Based on

1. Universidade de Passo Fundo, Faculdade de Educação Física e Fisioterapia, Curso de Fisioterapia, Passo Fundo, RS, Brasil.

2. Universidade de Passo Fundo, Faculdade de Educação Física e Fisioterapia, Programa de Pós-Graduação em Envelhecimento Humano, Passo Fundo, RS, Brasil.

3. Pontifícia Universidade Católica do Rio Grande do Sul, Faculdade de Educaçăo Física e Fisioterapia, Curso de Fisioterapia, Programa de Pós-Graduaçáo em Envelhecimento Humano, Passo Fundo, RS, Brasil.

4. Universidade de São Paulo, Universidade de Passo Fundo, Faculdade de Educaçáo Física e Fisioterapia, Programa de Pós-Graduaçáo em Envelhecimento Humano, Passo Fundo, RS, Brasil. 5. Universidade Federal de Santa Catarina, Universidade de Passo Fundo, Faculdade de Educaçáo Física e Fisioterapia, Programa de Pós-Graduaçáo em Envelhecimento Humano, Passo Fundo, RS, Brasil.

Submitted on December 09, 2017.

Accepted for publication on August 20, 2018

Conflict of interests: none - Sponsoring sources: Coordenação de Aperfeiçoamento de Pessoal de Nível Superior (CAPES), PROCAD No 71/2013.

Correspondence to:

BR 285, Bairro São José

99052-900 Passo Fundo, RS, Brasil.

E-mail: mathjorge5@gmail.com

(C) Sociedade Brasileira para o Estudo da Dor this, it is emphasized the importance of interdisciplinary preventive and treatment actions to this audience.

Keywords: Aged, Chronic pain, Health profile, Long-term care institutions for the elderly, Pain, Sarcopenia.

\section{RESUMO}

JUSTIFICATIVA E OBJETIVOS: A sarcopenia e a dor crônica são síndromes geriátricas que impactam negativamente a vida dos idosos acometidos, dos seus familiares e ma rotina dos serviços de saúde, como é o caso das instituiçôes de longa permanência para idosos. $\mathrm{O}$ objetivo deste estudo foi verificar a relação entre a sarcopenia e a dor crônica em idosas institucionalizadas. MÉTODOS: Estudo de corte transversal, de base populacional, realizado em 24 instituiçóes de longa permanência para idosos, no município de Passo Fundo/RS (dezembro 2016 - junho 2017). A populaçáo foi composta por 161 residentes nesses locais, submetidos a um instrumento estruturado em 23 blocos. Neste estudo utilizou-se os blocos A (tipo de instituição), B (variáveis sociodemográficas), $\mathrm{F}$ (sarcopenia) e $\mathrm{G}$ (dor crônica). Os blocos A, B e G foram avaliados por meio do autorrelato do idoso e o bloco $\mathrm{F}$ por meio do Questionário SARC-F. A análise estatística utilizou a estatística descritiva e o teste Qui-Quadrado com relaçáo de Pearson $(\mathrm{p} \leq 0,05)$.

RESULTADOS: A amostra foi composta por 79 idosas (81,38 $\pm 8,79$ anos). A maioria com 80-89 anos, residentes em instituiçóes privadas, brancas, viúvas e com escolaridade de 1 a 8 anos. Observou-se que $62 \%$ apresentaram sarcopenia e $41,8 \%$ apresentaram dor crônica, sendo que houve associação dessas variáveis $(\mathrm{p}=0,033)$. Não se observou associação entre a sarcopenia ou a dor crônica com a faixa etária ( $\mathrm{p}>0,05)$.

CONCLUSÃO: Houve associação entre a sarcopenia e a dor crônica em idosas institucionalizadas. A partir disso, ressalta-se a importância de ações interdisciplinares de prevenção e tratamento destinadas a esse público.

Descritores: Dor, Dor crônica, Idoso, Instituiçáo de longa permanência para idosos, Perfil de saúde, Sarcopenia.

\section{INTRODUCTION}

The increasing aging process of the population is not only restricted to developed countries but also applies to the reality of developing countries such as Brazil. This trigger social, economic and health changes, requiring long-term care for the elderly who face difficulties in their daily activities and/or those whose family does not have the financial, physical or emotional conditions to provide such care, extremely specialized ${ }^{1}$. 
About 100 million people in the world have some type of chronic musculoskeletal pain, being the elderly those that suffer greater consequences. Plan, implement preventive programs, and control symptoms are necessary actions to maintain and promote the functionality and quality of life (QoL) of those individuals ${ }^{2}$. In Brazil, about $85 \%$ of the elderly have some kind of chronic disease, and 10\% of these still have other concomitant diseases. Longevity also brings about an increase in the number of elderly people with functional limitations and who need constant special care ${ }^{3}$.

After the third decade of life begins the process of loss of the reserves, especially bone and muscle $e^{4}$. The loss of mass, strength and muscle function is called sarcopenia, which is closely linked to aging 5 . Its etiology involves several factors, such as genetic and metabolic aspects, lifestyle, hunger, semi-starvation, inflammatory diseases, muscular atrophy due to neuromuscular insufficiency, reduced mobility or chronic hypoxia, which can cause general injuries in the body perceived during lifetime, and reduction of the physiological capacity of the cardiovascular, respiratory, neuromuscular and metabolic systems ${ }^{5,6}$. Generally speaking, sarcopenia results from the imbalance between the degradation and synthesis of proteins ${ }^{7}$ and may be linked to the increased morbidity and mortality in middle-aged and old people.

Due to the current demographic transition, there was an exacerbated increase of frail older people requiring specialized care $^{9}$. Due to the functional impairment and the implications on the family, the community, public health and life of the elderly, there was an increase in search for long-term institutions for the elderly (LTCI), a place that provides full care to the elderly, dependent or not, without family or household conditions to stay in their origin community. The effects of institutionalization on the elderly cause greater vulnerability and dependence, which negatively influences the QoL and their well-being ${ }^{10}$.

The association between functional impairment, gender and age group shows that women and the long-living are the most susceptible to develop disabilities. Thus, the preventive and health promotion actions should be directed to those individuals. The functional impairment of the elderly has become a public health problem, impacting the individual, their family and health services. It is the role of health professionals to identify such changes and their related factors early, and it should be incorporated into the routine of the basic health services at all levels of care ${ }^{11}$.

The objective of this study was to verify the relationship between sarcopenia and chronic pain in the institutionalized old women.

\section{METHODS}

This is a cross-sectional population-based study that is part of a project entitled "Aging and longevity patterns: biological, educational and psychosocial aspects of institutionalized old people" (PROCAD) developed by the Post-Graduation Program in Human Aging of the University of Passo Fundo.
The study was conducted in the city of Passo Fundo, from December 2016 to July 2017. Passo Fundo is one of the most populated cities of Rio Grande do Sul, Brazil, located in the North of the State, $293 \mathrm{~km}$ from the capital, Porto Alegre. The estimated population is 198,799 thousand inhabitants, and of these, 22,222 are 60 years old or above ${ }^{12}$. The city is an important regional health and education hub, and it also stands out in the sectors of agriculture, trade, and services. There are 24 LTCI, which houses about 450 senior citizens. For the sample calculation, the formula " $n=Z^{2} \cdot p \cdot(1-p) / e^{2}$ " was used, where the letter " $n$ " corresponds to the desired sample size, the letter " $Z$ " to the acceptable deviation average value to reach the desired confidence level (the most commonly used value for this type of calculation was adopted: 1.96), the letter "p" corresponds to the expected ratio $(73.3 \%$, was adopted taking in consideration the results of Reis and Torres, $2011^{1}$ ) and the letter "e" corresponds to the margin of error allowed (the most commonly used value for this type of calculation was adopted: 0.05). Thus, the sample size required to meet the objective of this study would be 300 individuals. The inclusion criteria were females, with 60 years of age or more, living in an LTCI in the city of Passo Fundo/RS. The exclusion criteria were patients with acute pain, unable to ambulate, to verbalize or to carry out the proposed tests (restricted to bed or wheelchair), hospitalized on the day of the meeting with the research team, with neuromotor sequels or in the acute stage of degenerative diseases. Eligible individuals who refused to participate or did not sign the Free and Informed Consent Form (FICT) Were considered as losses. The participants in the study signed the FICT.

The interviewers' team was composed of MA students of the Post-graduation Program in Human Aging, students of the healthcare area, that could be a scientific initiation fellow or not, all connected to and collaborators of the UPF. All team members were introduced to the research project and were previously trained in how to approach to the elderly, also receiving instructions and clarification about the information on the questionnaire. All the steps were supervised and coordinated by professors from the UPF.

The instrument used for data collection was a questionnaire elaborated by the Ph.D. researchers of the UPF, of the University of Campinas, and of the Catholic University of Brasilia. It consists of 23 blocks, but in this study, the variables used were from the blocks A (the type of LTCI), B (age, color, marital status, education), F (sarcopenia) and G (chronic pain). The information from the A and B blocks were evaluated in an interview with the people responsible for the Administrative Department of LTCI. Block G that addresses the presence or not of chronic pain was analyzed by the self-report of the patients (revised with the responsible health team). Block $F$ was carried out with the SARC-F questionnaire, translated and adapted to the Portuguese language.

The SARC-F questionnaire includes five components: strength (if the individual is able to lift $2.5 \mathrm{~kg}$ ), ambulation (if the individual is able to walk across a room or in his room), rise from a chair (if the individual is able to get up from a 
chair) climb stairs (if the individual is able to climb a flight of 10 stairs) and falls (how many times the individual has fallen in the last year). The scores range from zero to 2 points, and for the first four the interpretation is zero = no difficulty, $1=$

Table 1. Sample characterization. Passo Fundo/RS, 2017

\begin{tabular}{|c|c|c|}
\hline Variables & $\mathrm{n}$ & $\%$ \\
\hline \multicolumn{3}{|l|}{ Age group (years) } \\
\hline $60-69$ & 08 & 10.1 \\
\hline $70-79$ & 23 & 29.1 \\
\hline $80-89$ & 34 & 43.0 \\
\hline 90 or older & 14 & 17.8 \\
\hline \multicolumn{3}{|l|}{ Type of LTCI } \\
\hline Private & 42 & 53.2 \\
\hline Philanthropic & 37 & 46.8 \\
\hline \multicolumn{3}{|l|}{ Color } \\
\hline White & 70 & 88.6 \\
\hline Brown & 05 & 6.3 \\
\hline Black & 02 & 2.5 \\
\hline Did not answer & 02 & 2.5 \\
\hline \multicolumn{3}{|l|}{ Marital status } \\
\hline Widow & 50 & 63.3 \\
\hline Single & 17 & 21.5 \\
\hline Divorced/separated & 09 & 11.4 \\
\hline Married/with partner & 03 & 3.8 \\
\hline \multicolumn{3}{|l|}{ Education } \\
\hline Illiterate & 13 & 16.5 \\
\hline 01 to 08 years of education & 50 & 63.3 \\
\hline 09 years of education or more & 14 & 17.7 \\
\hline Did not answer & 02 & 2.5 \\
\hline \multicolumn{3}{|l|}{ Sarcopenia } \\
\hline Yes & 49 & 62.0 \\
\hline No & 30 & 38.0 \\
\hline \multicolumn{3}{|l|}{ Chronic pain } \\
\hline Yes & 33 & 41.8 \\
\hline No & 46 & 58.2 \\
\hline
\end{tabular}

$\mathrm{n}=$ absolute value; $\%$ = relative value; $\mathrm{LTCl}=$ long-term care institution.

Table 2. Relationship between sarcopenia and chronic pain. Passo Fundo/RS, 2017

\begin{tabular}{lccc}
\hline & $\begin{array}{c}\text { With chronic } \\
\text { pain }\end{array}$ & $\begin{array}{c}\text { Without } \\
\text { chronic pain }\end{array}$ & p-value \\
\hline With sarcopenia & $25(51.0 \%)$ & $08(26.7 \%)$ & $0.033^{*}$ \\
Without sarcopenia & $24(49.0 \%)$ & $22(73.3 \%)$ & \\
\hline$n=$ absolute value; \% $\%$ relative value; * $=$ statistical difference. &
\end{tabular}

some difficulty and 2 = great difficulty or unable to do, while for the last, the interpretation is zero $=$ no falls in the last year, $1=1-3$ falls in the last year and $2=4$ or more falls in the last year. Those individuals with 04 points or more in the total sum of the scores of the five components were indicative of sarcopenia. The SARC-F features an excellent specificity (94.2-99.1\%), but low sensitivity (3.8-9.9\%) for the classification of sarcopenia ${ }^{13}$.

This study was approved by the Human Research Ethics Committee of the UPF under opinion number 2.097.278. The study is in accordance with the guidelines of the Resolution 466/2012, of the National Council of Health, which addresses the regulatory standards and the ethical aspects of human research, and with the Declaration of Helsinki.

\section{Statistical analysis}

Data analysis was performed using statistical software. The descriptive statistics were used for the sample characterization and Pearson's Chi-square test for the cross-checking of data, considering significant a $\mathrm{p} \leq 0.05$.

\section{RESULTS}

The study population consisted of 161 aged living in an LTCI in the city of Passo Fundo/RS. Based on the inclusion and exclusion criteria, the sample had 79 old women. The average age of the subjects was $81.38 \pm 8.79$ years (61-100 years). Table 1 shows the data concerning the sample characterization.

It was observed that most of the sample was concentrated in the 80-89 years age group, living in LTCI. They were predominantly white, widows and with 1 to 8 years of education. Still, the majority of individuals had indicative of sarcopenia, and an expressive number of subjects reported suffering from chronic pain. Table 2 shows the relationship between the presence of sarcopenia and chronic pain in the sample.

There was an association between sarcopenia and chronic pain, and individuals with sarcopenia showed a higher prevalence of chronic pain. Table 3 shows the relationship between sarcopenia and chronic pain in the age groups of the sample.

No relationship was found between sarcopenia and the age groups, nor between chronic pain and age groups.

\section{DISCUSSION}

Some information found in this study with respect to sociodemographic aspects of the institutionalized old women corroborate the literature. It was observed in previous sources that the

Table 3. Relationship between sarcopenia and age groups. Passo Fundo/RS, 2017

\begin{tabular}{|c|c|c|c|c|c|}
\hline & 60-69 years & $70-79$ years & 80-89 years & 90 years or older & $\mathrm{p}$-value \\
\hline With sarcopenia & 05 (62.5\%) & $14(60.9 \%)$ & $23(67.6 \%)$ & $07(50.0 \%)$ & 0.896 \\
\hline Without sarcopenia & 03 (37.5\%) & 09 (39.1\%) & $11(32.4 \%)$ & $07(50.0 \%)$ & \\
\hline With chronic pain & 05 (62.5\%) & 08 (34.8\%) & $16(47.1 \%)$ & $04(28.6 \%)$ & 0.363 \\
\hline Without chronic pain & 03 (37.5\%) & $15(65.2 \%)$ & $18(52.9 \%)$ & $10(71.4 \%)$ & \\
\hline
\end{tabular}

$\mathrm{n}=$ absolute value; $\%$ = relative value. 
geriatric population has a predominance of females and with low educational level ${ }^{14,15}$. The latter is often presented in studies of geriatric profiles because education was little valued in the childhood time of today's senior citizens, especially for women ${ }^{16}$. Although the literature shows that most Brazilian institutions are philanthropic, women predominate among the residents, confirming the "feminization of the old age" 17.

The institutionalized elderly may show a gradual process of deterioration in their functional capacity and autonomy, after being admitted in an $\mathrm{LTCI}^{15}$, which could be linked with the onset of health problems, sarcopenia, and chronic pain, among them. Also, the literature points out that old women have the worst QoL scores compared to old men, especially in physical aspects $^{18}$, making of interest the selection of this subject in the present study aimed to women living in LTCI.

Chronic pain is experienced by many institutionalized senior citizens ${ }^{14}$, and sarcopenia affects most of these individuals. In Brazil, its prevalence is around $15.4 \%$, and it is slightly higher among women (16.1\%) compared to men (14.4\%). Regarding the age, there is a dramatic increase in the prevalence of sarcopenia, being $7.6 \%$ in men and $7.7 \%$ in women in the 60-69 years age group, $19.5 \%$ in men and 19, $4 \%$ in women in the $70-79$ years age group and $44.7 \%$ in men and $46.6 \%$ in women in the $80-89$ years age group ${ }^{19}$. In addition to the above, other factors such as malnutrition, physical inactivity, low levels of vitamin D and low intake of protein are related to sarcopenia ${ }^{20}$. As a result, the present study sought to verify the occurrence of sarcopenia and chronic pain in institutionalized old women, and the relationship between these variables.

The loss of muscle mass is considered physiological with the aging process, and this points to divergences among the authors in classifying sarcopenia as a disease or not. Yet, sarcopenia causes a substantial loss of muscle mass creating a functional dependency and interfering negatively with the individual's quality of life $\mathrm{f}^{6}$. After the age of 60, there is an increase in the prevalence of sarcopenia, and Brazil is ranked the second country in the world in this respect. Sarcopenia is often associated with low physical capacity, functional limitations, disability, comorbidities, social status, bad life habits, and falls ${ }^{21}$, and this set of factors is also related to the institutionalization of the elderly.

A study that aimed to investigate the factors associated with sarcopenia in different age groups of Korean individuals found that in the 65-year or older age group there has been a higher occurrence of sarcopenia. This prevalence was associated with individuals suffering from problems of mobility, difficulty in daily life activities and pain ${ }^{22}$, which corroborates the present study where an association between sarcopenia and chronic pain in institutionalized old people was found.

A study indicated a prevalence of $73.3 \%$ of chronic pain in aged living in an $\mathrm{LTCI}^{1}$, which differs from the results of the present study, where the majority of the individuals did not report to suffer from chronic pain, even despite the expressive number of cases $(41 \%)$.

Old people suffering from pain may be prone to cocoon and sedentarism, low self-esteem and the abandonment of the self- care. Functional impairment may result in mental and physical dependency and inability to perform daily activities ${ }^{1}$, reinforcing the idea that sarcopenia can be triggered by starvation of the elderly suffering from pain chronic.

The current results corroborate the study by Barbosa et al. ${ }^{23}$ that studied 124 institutionalized elderly and evidenced the predominance of women, in the 70-80-year age group, single, with a basic education that did not practice physical activities regularly. Chronic pain prevailed in $58.1 \%$ of the sample, and the long-living elderly showed $70 \%$ more chance of reporting chronic pain compared to the non-long-living elderly.

It is believed that the advanced age found in most of the studies conducted in an LTCI can be attributed to the increased dependency of old people in carrying out their daily activities, therefore requiring full care for their physical and cognitive health. In addition, old people living in an LTCI have more pain and reduced mobility when compared to the non-institutionalized individual $s^{24}$. Which suggests that institutionalization may be a determining factor for the association of sarcopenia and chronic pain, as pointed out in this study.

Reinforcing the previous comment, a study conducted with 75 non-institutionalized old women, randomized in a group with sarcopenia $(n=24)$ and control group $(n=51)$, identified that the pain was not a determining factor in the development of sarcopenia in the sample ${ }^{25}$, which contradicts the current study, where it was observed the association between sarcopenia and chronic pain in the institutionalized old individuals.

This study is not limitation-free. Since it is a study of great magnitude, it required a large team to perform the data collection. Therefore, the interviewers and the test assistants were not the same who collected the data of all individuals included in the survey. To minimize possible bias, they have been trained and instructed in advance, as explained in the "methods" section of this study. In addition, the number below the expected sample size and the non-differentiation of individuals by disease or other causes of chronic pain are factors that limit but do not impair the data generation encouraging future research within this theme.

\section{CONCLUSION}

There was an association between sarcopenia and chronic pain in the institutionalized old women. This fact highlights the importance of interdisciplinary prevention and treatment actions aimed at this audience.

\section{REFERENCES}

1. Reis LA, Torres GV. Influência da dor crônica na capacidade funcional de idosos institucionalizados. Rev Bras Enferm. 2011;64(2):274-80.

2. Kayser B, Miotto C, Dal Molin V, Kummer J, Klein SR, Wibelinger LM. Influência da dor crônica na capacidade funcional do idoso. Rev Dor. 2014;15(1):48-50.

3. Gonçalves LH, Alvarez AM, Sena EL, Santana LW, Vicente FR. Perfil da família cuidadora de idoso doente/fragilizado do contexto sociocultural de Florianópolis, SC. Texto Contexto - Enferm. 2006;15(4):570-7.

4. Keller K, Engelhardt M. Strength and muscle mass loss with aging process. Age and strength loss. Muscles Ligaments Tendons J. 2014;3(4):346-50.

5. Martín-Ponce E, Hernández-Betancor I, González-Reimers E, Hernández-Luis R, Martínez-Riera A, Santolaria F. Prognostic value of physical function tests: hand grip strength and six-minute walking test in elderly hospitalized patients. Sci Rep. 2014; $4: 7530$ 
6. Leite LE, Resende TL, Nogueira GM, Cruz IB, Schneider RH, Gottlieb MG. Envelhecimento, estresse oxidativo e sarcopenia: uma abordagem sistêmica. Rev Bras Geriatr Gerontol. 2012;15(2):365-80.

7. Teixeira Vde O, Filippin LI, Xavier RM. Mechanisms of muscle wasting in sarcopenia. Rev Bras Reumatol. 2012;52(2):252-9. English, Portuguese.

8. Ling CH, Taekema D, de Craen AJ, Gussekloo J, Westendorp RG, Maier AB. Handgrip strength and mortality in the oldest old population: the Leiden 85 -plus study. CMAJ. 2010;182(5):429-35.

9. Cordeiro LM, Paulino JL, Bessa ME, Borges CL, Leite SF. Qualidade de vida do idoso fragilizado e institucionalizado. Acta Paul Enferm. 2015;28(4):361-6.

10. Gallon D, Gomes AR. Idosos institucionalizados e os efeitos do exercício no processo de envelhecimento musculoesquelético: uma revisão. RBCEH. 2012;8(1):137-47.

11. Brito KQ, de Menezes TN, de Olinda RA. Functional disability and socioeconomic and demographic factors in elderly. Rev Bras Enferm. 2015;68(4):548-55, 633-40. English, Portuguese.

12. Instituto Brasileiro de Geografia e Estatística. Cidades. Brasília, Brasil: 2017. Disponível em: <https://cidades.ibge.gov.br/xtras/perfil.php?.codmun=431410>. Acesso em: 19 de novembro de 2017.

13. Malmstrom TK, Miller DK, Simonsick EM, Ferrucci L, Morley JE. SARC-F: a symptom score to predict persons with sarcopenia at risk for poor functional outcomes. J Cachexia Sarcopenia Muscle. 2016;7(1):28-36.

14. Barbosa MH, Silva LC, Andrade EV, Luiz RB, Bolina AF, Mattia AL, et al. Evaluation of chronic pain in the institutionalized elderly. REME Rev Min Enferm. 2012;16(1):63-8.

15. Rosa PV, Glock L, Berlezi EM, Rossato DD, Rosa LH. Perfil dos idosos residentes em instituiçóes de longa permanência da região sul do país. RBCEH, Passo Fundo. 2011;8(1):38-47.
16. Alves-Silva JD, Scorsolini-Comin F, Santos MA. Idosos em instituiçốes de longa permanência: desenvolvimento, condiçóes de vida e saúde. Psicol Reflex Crit. 2013;26(4):820-30.

17. Camarano AA, Kanso $S$. As instituiçôes de longa permanência para idosos no Brasil. Rev Bras Estud Popul. 2010;27(1):232-5.

18. Castro LD, Freitas C, Gonçalves M, Lucca MG, Melo M, Silva JF, et al. Envelhecimento e qualidade de vida: um estudo comparativo entre mulheres e homens idosos de Uberlândia, Minas Gerais. E-Rac. 2014;4(1):1-11.

19. Alexandre TS, Duarte YA, Santos JL, Wong R, Lebrăo ML. Prevalence and associated factors of sarcopenia among elderly in Brazil: findings from the SABE Study. J Nutr Health Aging 2014;18(3):284-90.

20. Freitas AF, Prado MA, Cação JC, Beretta D, Albertini S. Sarcopenia e estado nutricional de idosos: uma revisão de literatura. Arq Ciênc Saúde. 2015;22(1):9-13.

21. Diz JB, Queiroz BZ, Tavares LB, Pereira LS. Prevalência de sarcopenia em idosos: resultados de estudos transversais amplos em diferentes países. Rev Bras Geriatr Gerontol. 2015;18(3):665-78.

22. Bae E, Kim Y. Factors affecting sarcopenia in Korean adults by age groups. CMAJ 2017;8(3):169-78

23. Barbosa MH, Bolina AF, Tavares JL, Cordeiro AL, Luiz RB, de Oliveira KF. Sociodemographic and health factors associated with chronic pain in institutionalized elderly. Rev Lat Am Enfermagem. 2014;22(6):1009-16. English, Portuguese, Spanish.

24. Santos AR, Lopes BM, Lorenzini M, Resende TL. Depressão e mobilidade em idosos com dor crônica, institucionalizados e năo institucionalizados. Rev Graduaçâo. 2011;4(2):1-18.

25. Lima AR, Portes LA, Oliveira NC, Alfieri FM. Limiar de tolerância de dor à pressão, estilo de vida, força muscular e capacidade funcional em idosas com sarcopenia. Acta Fisiatr. 2016;23(2):73-7. 